\title{
Chapter 2 \\ Mapping the Qualitative Migration \\ Research in Europe: An Exploratory \\ Analysis
}

\author{
Evren Yalaz and Ricard Zapata-Barrero
}

\subsection{Introduction ${ }^{1}$}

While half a century ago migration research was a peripheral area of study within traditional academic disciplines, today it has become a firmly established multidisciplinary field with an increasing number of research centres, publication outlets, and academic programs. Almost all recognized universities in Europe make migration studies visible through their lines of research, master and doctoral programs, research groups, centers and institutes. The key academic editorials increasingly publish collections, handbooks, textbooks and companions on the key issues of migration studies, such as diversity, citizenship, integration, mobility, borders, and migration policies. For instance, IMISCOE has recently released a textbook series edited by Marco Martiniello and Jan Rath $(2010,2012,2014)$ that assembled the studies on international migration and immigrant integration in Europe. The European research agenda on migration studies is multi-varied, and always connected to social, political and economical processes in Europe. The different programs of the IMISCOE Annual Conferences (www.imiscoe.org) clearly illustrate this multi-sited, multi-disciplinary and multi-level analysis.

This chapter aims to reflect on the current state and overtime development of Qualitative Migration Research in Europe (QMR-E). For this purpose, we have conducted paper-by-paper analysis on original articles published between 2000 and 2016 in the Journal of Ethnic and Migration Studies (JEMS) and Ethnic and Racial

\footnotetext{
${ }^{1}$ We would like to thank John Solomos and GRITIM-UPF researchers for their invaluable comments on the earlier versions of this chapter.

E. Yalaz $(\bowtie) \cdot$ R. Zapata-Barrero

Political and Social Sciences Department, University of Pompeu Fabra - GRITIM-UPF,

Barcelona-Catalonia, Spain

e-mail: evren.yalaz@upf.edu; ricard.zapata@upf.edu
} 
Studies (ERS), two leading peer-reviewed journals in the field of migration research. ${ }^{2}$ In total, we have identified more than 2400 articles published in this period and looked for those that are based on qualitative empirical research in migration studies conducted in Europe. Six hundred twenty-seven original articles met our search criteria of QMR-E and were examined further. The main objective of this exploratory analysis is to map the continuities and changes taking place in QMR-E with respect to their research methods, designs, research sites and groups, levels of analysis, and topics. In this respect, we aim to identify the dominant trends and existent gaps in QMR-E literature, so that we could invite scholars to deepen the existing research agenda and to engage in new research directions.

One of the striking findings of this exploratory analysis is that scholarly interest in migration studies unprecedentedly increased over the last 16 years. Today, the number of issues and original articles released is three times more than in the early 2000s. In this period, the QMR-E articles kept on growing in quantity and accounted for approximately one-quarter of the total original articles released by these two journals. The analysis also demonstrates that QMR-E articles are diverse in terms of their qualitative methods and designs, groups and countries of study, the way they categorise migrants, levels of their analysis, and the primary migration issues that they focus on. Despite this diversity, we can still argue that the increasing interest in qualitative research in European Migration Studies makes it evident that migration scholars focus on detailed examination of their cases and have direct contact with their objects of analysis.

Before articulating the outcomes of this exploratory analysis, the main methodological criteria that were followed to collect and analyze the information will be introduced. In the second section, the main findings on the increasing interest in migration studies and qualitative research will be presented. In the third section, we will examine the current state and development of QMR-E following the criteria of analysis being proposed. In the concluding section, we will try to go beyond the descriptive analysis and infer some tentative generalizations in terms of patterns, gaps and new directions in QMR-E.

\footnotetext{
${ }^{2}$ While mainly practical issues limited our analysis to two journals, we had some good reasons for selecting JEMS and ERS. First, both are the leading journals mapping migration studies in Europe and have a long publication history. Therefore, they have made overtime analysis possible. Today, there are many other journals dedicated to migration studies, but relatively younger journals, such as Migration Studies (since 2013), Comparative Migration Studies (since 2015), and Journal of Migration History (since 2015) would not allow us to examine the state of QMR-E at the beginning of the millennium. Secondly, because of our European focus, we have opted for journals with editorials based in Europe. Therefore, other leading migration research journals, such as International Migration, which is currently edited at Georgetown University's Institute for the Study of International Migration (ISIM), and International Migration Review, by the Center for Migration Studies of New York (CMS) stayed out of our selection. Thirdly, we assume that peerreviewed journals with relatively higher citation indices and impact factors would have more visibility and, therefore, potentially have more influence on the migration research agenda. Fourthly, we selected journals with an explicit focus on migration research. In this respect, other related journals, such as Global Networks, Identities, and Ethnicities, that publish migration-related work but do not prioritize migration research in their journal description were not taken into consideration.
} 


\subsection{Methodology: Main Criteria of Analysis}

This analysis focuses on six main areas. Firstly, we examined the main research methods used in the QMR-E articles. In addition to learning about relative distribution of traditional qualitative data collection methods, i.e. interviews, participant observations, and document analysis, we asked whether and to what extent scholars adopt relatively new qualitative tools such as internet-mediated research and visual analysis. Moreover, we inquired the extent of which qualitative migration scholars working in Europe combine qualitative and quantitative tools.

Second, we examined the status of comparative research in QMR-E. While the importance of comparative designs for understanding migration-related topics is highly emphasized, we still do not know the extent to which comparative research is prevalent in QMR-E. This analysis included an examination of relative distribution of comparative QMR-E overtime and the types of comparisons - cross-location (among territorial settings), cross-group (among migrant groups), cross-meso level (among organisations and institutions), and cross-time (among different periods) that have been conducted.

Third, we focused on the ways that migrants are categorised in the QMR-E articles. Our main questions included: are migrants predominantly categorised with respect to their countries of origin, e.g. Turks in Germany, Poles in the UK? Is there an increasing attention to the category of generation and therefore second-generation migrants? What about the category of religion? Is the so-called feminization of migration flows (Castles and Miller 1993) and feminization migration scholarship (King et al. 2011) translated into categorising migrants with respect to gender categories? What about legal status? Is there more research considering migrants in terms of their legal status (i.e. documented, undocumented, asylum seekers, and refugees) in their receiving countries?

Fourth, we wanted to find out about the geographical distribution of countrycases in QMR-E articles. We asked whether and in which ways some countries are studied more than others. Do migrants from certain countries tend to be studied more often than others? Is there an overtime change in the distribution of research contexts and countries of origin? Previous analysis on JEMS already demonstrated the changing geographies of host and sending country contexts (King et al. 2011). There has been a shift away from the UK as primary host country context towards Southern and Eastern Europe. Meanwhile, the publications on UK's traditional sending regions such as South Asia and Caribbean have been declining. There has been a rise in the scholarly attention on "newer" sending regions such as Eastern Europe, Middle East, and East Europe. In this part, we checked whether these findings also hold true for QMR-E.

Fifth, we inquired the place of the multi-level analysis, which is the status of national-level analysis in QMR-E and whether local and transnational levels of analysis are on the rise. Some scholars have already been advocating against migration research at national-levels and have been critical of having nation-states as the basic unit of analysis (Wimmer and Schiller 2003; Amelina and Faist 2012). On the 
Fig. 2.1 Six criteria of analysis

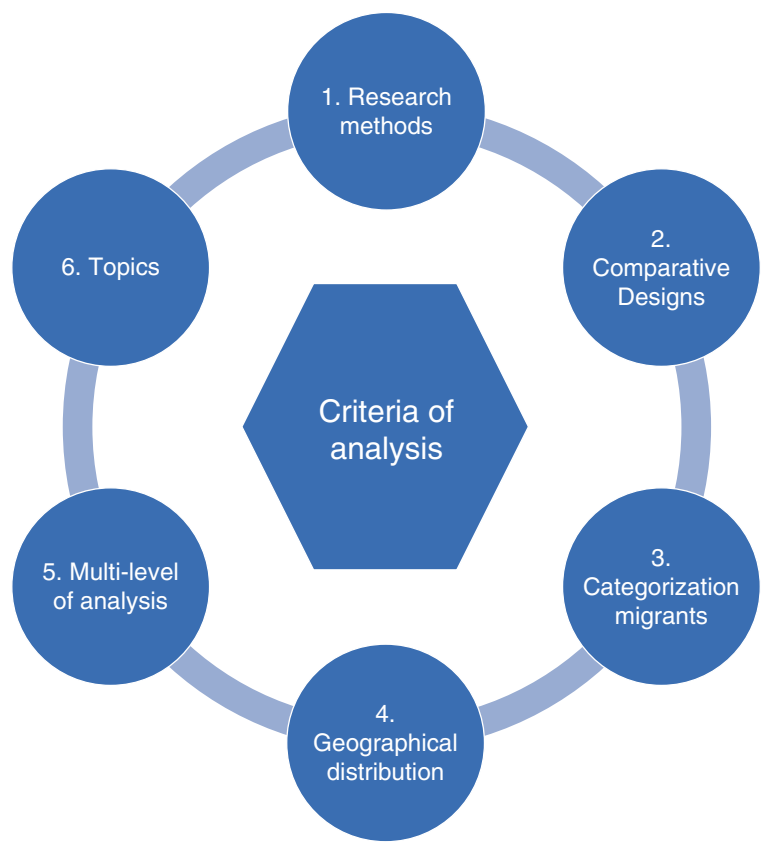

other hand, there has been growing interest in studying migration at local-levels (Schiller and Çağlar 2009; Zapata-Barrero et al. 2017) and at transnational level (Vertovec 1999; Levitt and Schiller 2004; Levitt and Jaworsky 2007).

Finally, we examined continuities and changes in terms of the topics studied by QMR-E. We particularly focused on overtime distribution of eight main topics, i.e. identity, integration, policy, discrimination/exclusion, citizenship, forced migration and asylum, borders and mobility, and youth and the second generation (Fig. 2.1).

To analyse the overtime patterns in QMR-E literature, we went over all the original articles published in JEMS and ERS between 2000 and 2016, and identified those meeting the general criteria of Qualitative Migration Research in Europe. The research included four main selection criteria: (1) qualitative research that excluded studies using only quantitative methods, but included mixed-methods; (2) empirical research that excluded field reviews, conceptual, and theoretical articles; (3) migration research that strictly focused on migration-related diversity and its related issues, and excluded studies on local minority groups, ethnic, racial, religious, and cultural studies without a migration focus; (4) research on Europe that included the cases from Central and Eastern Europe and Turkey, multi-sited studies with European and non-European cases, but excluded articles with only non-European research sites.

Those articles meeting our research criteria are further examined and coded according to the six main areas ${ }^{3}$ : (1) Qualitative research tools, e.g. interviews,

${ }^{3}$ Each article is coded by two researchers to ensure reliability. 
focus groups, participant observation, historical analysis, visual analysis, and mixed-methods; (2) Comparative research design (in case it exists) and its types, such as cross-location, cross-group, cross-time, and cross-meso level comparisons; (3) Categorisation of migrants, i.e. national, legal, class, religion, gender, geographical group categories; (4) Research sites (country and city information) and country of origin (if research includes a migrant group); (5) Multi-level analysis including transnational, European, national, and local levels; and (6) Research topics: in addition to including the keywords provided by the authors, we coded each article according to the list of research areas provided by IMISCOE on researcher's profile page (see Annex). Each article could have multiple topics. Section 2.4.6 presents the findings on eight highly repeated topics.

\subsection{A General Reading: The Number of Migration Research Is Rising, But so Is Qualitative Migration Research in Europe?}

While two decades ago migration research had a tiny presence in social scientific inquiry, today, growing scholarly interest in migration and migration-related topics is undisputable. Both JEMS and ERS demonstrated unprecedented increase in the number of issues and original articles they publish per year (see Fig. 2.2). JEMS used to release four issues and around 35 original articles a year up until 2003. It increased the number of yearly issues from 6 to 8 in 2004, from 8 to 10 in 2009, and from 10 to 12 in 2014. In 2016, it released 15 issues and more than 130 original articles. According to the journal's editors, such an expansion was a necessary step to respond to increasing number of submissions, while keeping the acceptance rate the same (King 2009; Statham 2016). ERS has also followed a similar trajectory.

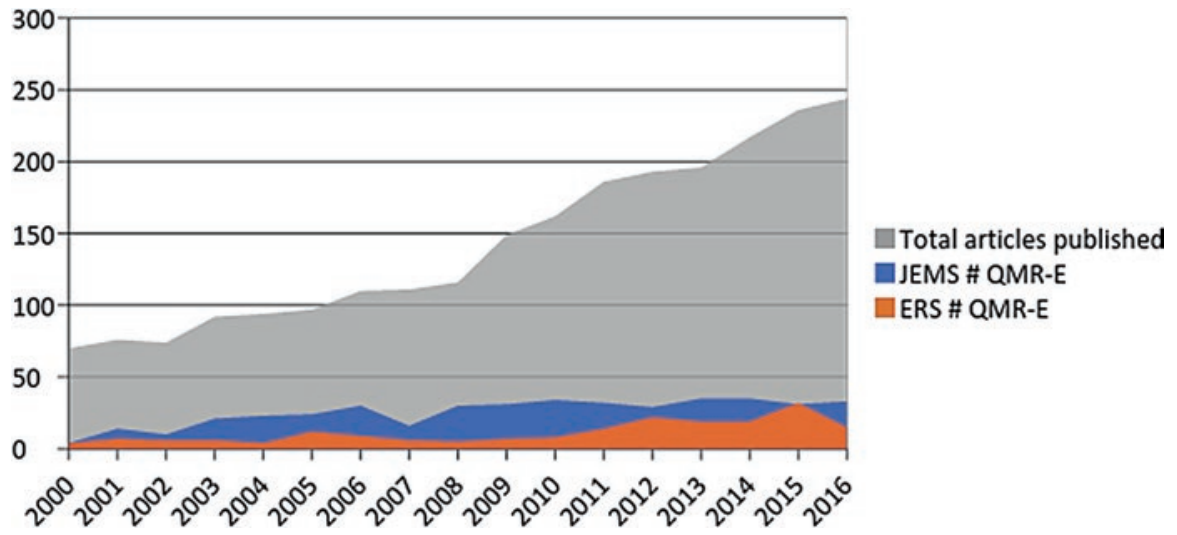

Fig. 2.2 Number of articles published in JEMS and ERS between 2000 and 2016 (Note: Figures exclude editorial introductions, book reviews, and debate articles) 
Table 2.1 Number of articles published by JEMS and ERS between 2000 and 2016

\begin{tabular}{l|l|l|l|l}
\hline & Yearly issues & Total articles & QMR-E articles & \% of QMR-E \\
\hline 2000 & 10 & 70 & 8 & 11.4 \\
\hline $2001-2002$ & 20 & 150 & 37 & 24.7 \\
\hline $2003-2004$ & 24 & 186 & 54 & 29 \\
\hline $2005-2006$ & 28 & 207 & 75 & 36.2 \\
\hline $2007-2008$ & 32 & 227 & 57 & 25.1 \\
\hline $2009-2010$ & 39 & 311 & 80 & 25.7 \\
\hline $2011-2012$ & 44 & 379 & 97 & 25.6 \\
\hline $2013-2014$ & 48 & 413 & 108 & 26.2 \\
\hline Total & $\mathbf{3 0 4}$ & 480 & 111 & 23.1 \\
\hline
\end{tabular}

Note: Figures exclude editorial introductions, book reviews, and debate articles

While in the early 2000s, six issues and around 40 original articles were published a year, today ERS releases more than 100 articles and 15 issues yearly including Ethnic and Racial Studies Review since 2014. Such expansion is a clear signal of strong scholarly interest in issues of migration, mobility, ethnic, racial, and cultural diversity.

Has this steep increase also translated into the number of QMR-E? Table 2.1 shows that the share of QMR-E had boosted in the early years of the 2000s. While in 2000 only $11 \%$ of the articles published in JEMS and ERS qualified for QMR-E criteria, this share increased rapidly over the next years and made a peak in 20052006. This period interestingly coincides with a time of rapid changes in Europe with the Eastern expansion of the European Union, with the emergence of new European destination countries in the South, and with the expansion of public and political debates on migration and mobility. Since then, there has been a constant increase in the number of QMR-E articles, while their share has been kept stable (approximately one-fourth of the total publications).

\subsection{Current State and Development of Qualitative Migration Research in Europe}

\subsubsection{Research Methods}

Interviews are essential tools of qualitative research. The analysis shows that three out of four QMR-E articles have used a typology of qualitative interviews. Some examples ${ }^{4}$ include semi-structured in-depth interviews with migrants (Søholt and

\footnotetext{
${ }^{4}$ It is important to note that the articles we cite from our research are not the key-representatives, but just illustrations of our main findings. We are fully aware that we could have cited other articles from our research pool of 627 QMR-E articles, but practical reasons obliged us to limit our references.
} 
Lynnebakke 2015; van Meeteren et al. 2015), with migrant activists (Cappiali 2016), expert interviews (Menz 2002; Helbling 2010; Wiesböck et al. 2016), biographical/ narrative interviews (Liversage 2009; Qureshi 2016), and problem-centered interviews (Konzett-Smoliner 2016; Verwiebe et al. 2016).

Unlike interviews in general, focus groups have been much less common. Only 55 articles in the works collected have used focus groups. Having said that, we must also note the increasing tendency to use focus groups in QMR-E. We have found out that in the last 8 years the number of articles has more than doubled compared to the first 8 years of the 2000s.

Participant observation has been another major tool of QMR-E. Near 34\% of the articles that we identified conducted some type of fieldwork and used the tools of participant observation. It must be noted that an overwhelming majority of the studies with participant observation (195 out of 210 participant observation articles) also conducted qualitative interviews. This confirms the already shared view that participant observation and interviews complement each other.

While it was relatively easier to detect the QMR-E articles using interviews, focus groups, and participant observation as data collection methods, the same was not true for finding out articles that used documents as primary sources. One obvious reason for this is that almost all studies use some sort of documents - let it be official documents, non-governmental reports, documents of political discourses, or written media sources. According to our analysis, $41 \%$ of QMR-E articles explicitly mentioned the use of documents in their analysis. As we will discuss later in this chapter, the majority of them were policy-related documents.

While the number of QMR-E has been increasing recently, we have found only 45 articles (7\%) that conducted historical analysis, namely studying migration dynamics in the past and/or tracing continuities and changes over time. Many of them engaged in overtime analysis to explain the current situation of a studied topic, e.g. analysing the development of official perspectives on migrant transnationalism since the 1960s in order to explain the current political discourse (Bouras 2013). Just a few of these historical analyses were dedicated only to archival study of the past (see, for example, Dedieu and Mbodj-Pouye 2016; Ryan 2003; Walaardt 2013). While historical research is still at the margins of migration studies, we think there is a rising scholarly interest in this field. The launch of the Journal of Migration History (since 2015) is a clear sign of this.

As we expected, new research tools such as internet-mediated research or visual analysis are rare. Only 18 of the articles were conducting internet-based research to collect qualitative data. While the internet-mediated research was almost nonexisting up until 2005, since then there has been a rapid increase. Almost one-third of articles using the internet as their main data collection site were published between 2015 and 2016. Recent examples include conducting online ethnographic research on social network sites to study migrant mobility and transnationalism (Schrooten et al. 2016), using Google street views to study social changes in times of super-diversity (Maly 2016), and analysis of webpages and online actors to study online Islamophobia (Ekman 2015). 


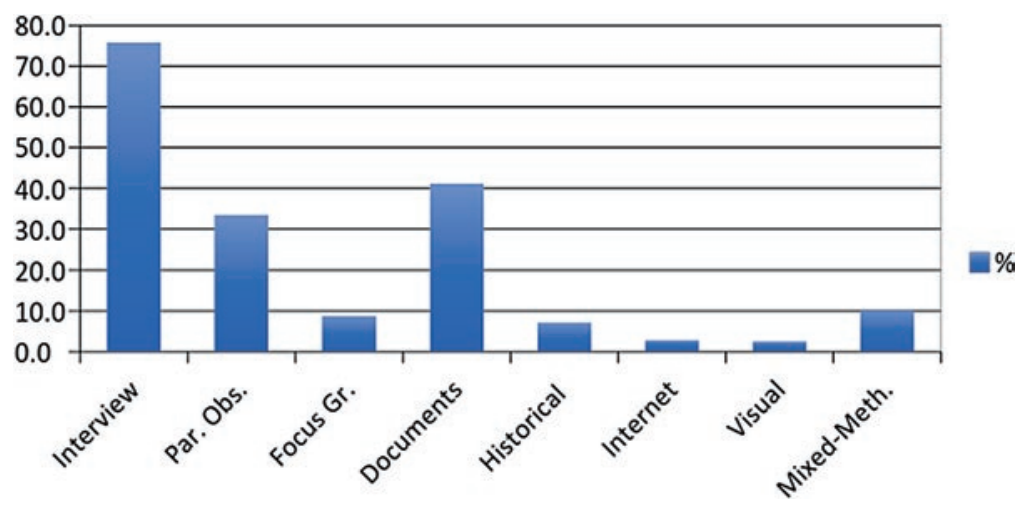

Fig. 2.3 Distribution of major methods in QMR-E (figures are in \%)

Fewer articles (only 16 in total) engaged in qualitative analysis of visual materials. While we found the first examples of visual research as of 2006, recently, more scholars have been engaging in this kind of qualitative research (for an overview of visual approaches to migration studies, see Martiniello 2017). For example, Fedyuk (2012) inquires about the role of photographs in transnational parental relations; Long et al. (2014) use mental maps and photo-elicitation to examine the role of leisure and sport spaces in new migrants' social inclusion; and Gawlewicz (2015) combines visual methods with qualitative interviews and a supplementary survey to study social remittances and transmission of attitudes between Polish migrants in the UK and their significant others in Poland.

While there has been a strong call for bridging the qualitative and quantitative divide by using multiple methods, our research shows that this call has not yet been translated into practice in European migration studies. Only 10\% of QMR-E articles combined qualitative and quantitative research tools. This ratio has been generally stable over time. Among mixed-method research, it has been a common practice to combine qualitative interviews with quantitative surveys (Parella et al. 2013; Wiesböck et al. 2016) as well as bringing together qualitative and census data sources (Hickman 2011; McGarrigle 2016). Moreover, another form of mixedmethod research included studies combining quantitative media content analysis with different forms of in-depth-textual research such as discourse analysis (for example, see Bauder 2008) (Fig. 2.3).

\subsubsection{Comparative Designs}

Comparative research is crucial to migration studies, since it is only through comparison that "we can de-centre what is taken for granted in a particular time or place" (Bloemraad 2013, p. 29). We found that 15\% of QMR-E articles used comparative research of various types. Despite its average low share, as Fig. 2.4 shows, 


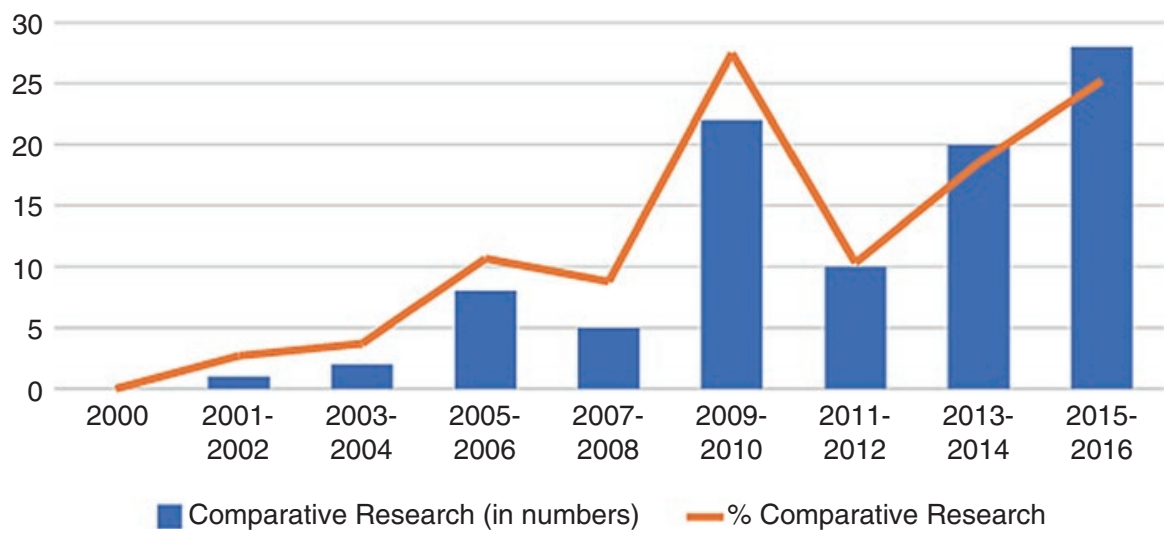

Fig. 2.4 Comparative research in QMR-E between 2000 and 2016 (in numbers and in \% of total QMR-E)

Table 2.2 Types of comparisons $(\%$ in total comparative QMR-E articles)

\begin{tabular}{l|r}
\hline Types of comparisons & \multicolumn{1}{l}{$\%$} \\
\hline Cross location & 58.3 \\
\hline Cross country & 34.4 \\
\hline Cross city & 7.3 \\
\hline Cross group & 32.3 \\
\hline Cross meso-level & 11.5 \\
\hline Cross time & 11.5 \\
\hline \multicolumn{2}{l}{ Total comparative research articles: 96}
\end{tabular}

the number of comparative research in QMR-E has been increasing recently. During 2015-2016, one-fourth of the articles that we studied conducted a type of comparative research.

We observed a wide-range diversity of comparative designs (see Table 2.2). The majority of comparative studies adopted cross-location comparisons, i.e. comparisons across countries, regions, cities, and neighbourhoods. While cross-country comparisons have been the most common design (33 out of 96 comparative QMR-E articles), recently, there has been an increase in the number of articles with cross-city comparisons. This finding supports the recent claims for a local-turn in migration scholarship (Zapata-Barrero et al. 2017). According to this exploratory analysis, the overwhelming majority of the cross-city comparisons were published after 2015 (for example, see Plöger and Becker 2015; Gebhardt 2016; de Graauw and Vermeulen 2016). On the other hand, one-third of the comparative QMR-E articles conducted cross-migrant group analysis. Some of the cross-group designs included: multiple groups (from different countries of origins) in a single national context, e.g. comparison of Ghanaian and Senegalese transnationalisms in Italy (Riccio 2008); multiple groups in multiple national contexts, e.g. comparing inclusion and exclusion of 
marginalized youth of North African origin in France and of Turkish origin in Germany (Loch 2009); and different migration waves of migrants from the same country of origin to the same receiving country context, e.g. comparing early and late economic migrants from Central and Eastern Europe to the UK (McDowell 2009).

While not as frequent as cross-location and cross-group comparisons, one-fifth of comparative QMR-E articles adopted either cross-meso level or cross-time designs. Some examples of comparisons at meso-level included comparing across political parties, host organisations (Batnitzky and McDowell 2013; Simpson 2015), and migrant organisations (De Tona and Lentin 2011). While some of the cross-time analysis compared policies over a period of time (Howard 2010), some others engaged in before-and-after type of comparisons, such as comparing high-skilled migration policies (Cerna 2016) or East-West cross-border labor mobility (Wiesböck et al. 2016) before and after the economic crisis.

\subsubsection{Categorisation of Migrants}

Today, it is a widely accepted fact that migrants cannot be moulded into a single category. This is probably one of the first consequences of migration-related analytical frameworks such as transnationalism (Levitt and Jaworsky 2007) and superdiversity (Vertovec 2007). Migrants navigate across multiple and intersecting identities, including their national-origin, ethnicity, race, class, religion, language, gender, and generation (Vertovec 2015). Our research shows that an overwhelming majority of QMR-E articles categorise migrants in relation to their national origin such as Turks in Germany, Poles in the UK, and Moroccans in France. In other words, almost one of every two QMR-E articles (47\%) identified migrants with their ethnic/national backgrounds brought from their country of origin. While some of these articles also referred to multiple identity categories such as class, gender, and generation, still their national and ethnic origin has been the most frequent one. Especially since the mid-2000s, an increasing number of scholars have been critical of using ethnic and national groups as units of analysis in migration research (Glick Schiller 2008; Glick Schiller and Çağlar 2013; Runfors 2016). Figure 2.5 shows that this call has been partly effective in QMR-E. While the articles considering migrants as national/ethnic groups have made a peak in 2007-2008, there is a recent observable decline. Despite the calls for post-racial and post-multicultural era, where nationality and ethnic origins are expected to lose their weight as category of analysis (Vertovec 2010; Matejskova and Antonsich 2015), national/ethnic forms of categorisation of migrants is far more common than the other categories in the current state of QMR-E.

While European migration research has its origins in studying guest workers in the 1950s and the 1960s (see, for example, Castles and Kosack 1973), today, the category of class has been largely left in the shadow. Only one in five QMR-E studies (97 articles) has categorised migrants with respect to their class/occupational status. Moreover, one-third of these articles classifying migrants with their class 


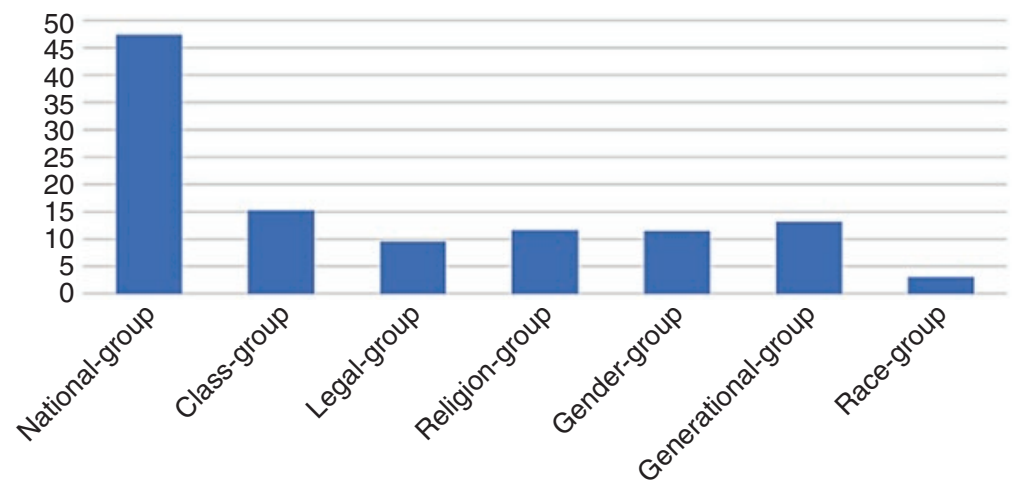

Fig. 2.5 Distribution of categorisation of migrant group categories (in \% of total QMR-E)

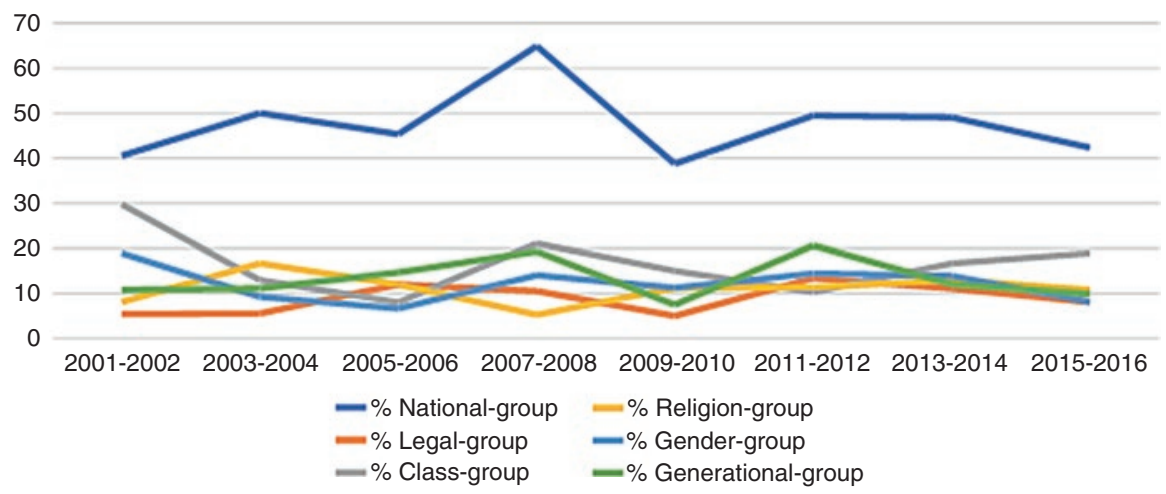

Fig. 2.6 Categorisation of migrants over time (figures in \% of total QMR-E)

status had the UK as the country of destination. Another important observation is that the category of class has expanded beyond the concept of "guest workers" and included wide-range of diversity, including migrant entrepreneurs (Kloosterman et al. 2016), high-skilled professional migrants (Ryan 2015), and domestic migrant workers (Anderson 2010).

As the so-called "refugee crisis" has hit Europe after the outbreak of the Syrian civil war, our expectation was to observe increasing number of studies that categorised migrants with respect to their legal status, such as refugees, asylum seekers, documented or undocumented migrants. However, Fig. 2.6 shows that the QMR-E studies considering migrants with respect to their legal categories have been more or less stable over time. One possible explanation for this is that such studies might be opting for specialized journals on the topic of forced migration, such as Journal of Refugee Studies, as their publication outlet. Another possible factor is: as qualitative data collection methods require longer duration of research, on-going developments might not have shown their presence in QMR-E yet. A third potential hypothesis could be that many studies focusing on migrants' legal-status might be concerned 
with the issues of democracy, human rights and liberalism at normative and theoretical levels and therefore did not qualify under our empirical research criteria.

While migration/religion nexus has been at the centre of many policy and public debates, we observed that few scholars categorised migrants with respect to their religion. This is also true for studies identifying migrants with racial categories. Here, we must note that our article-selection criteria excluded certain research on religious and racial groups, if these groups are considered as local minorities without any emphasis on their migration background. For example, some studies on Muslims in European countries did not meet our criterion of "migration studies", if they study Muslims as a minority group without referring to their migration history. Our findings show that 73 QMR-E articles used the category of religion while defining migrants in the study. What is more, almost half of them (30) studied the UK as the host country context.

Feminization of migration has been documented since a long time ago (Castles and Miller 1993). As women increase their share among international migrants, scholars expected to see gender becoming a prominent category in future migration studies (Lee et al. 2014). Despite these expectations, we have not observed an increase in the number of articles that categorised migrants with respect to gender categories. According to our research, 72 QMR-E articles (11\%) focused on gender category while studying migrants. This insufficient attention to the gender category in migration studies makes specific conditions and experiences of migrant women invisible and occults gender asymmetries that are (re)produced at different migratory and settlement stages (Lutz 2010).

Last but not least, despite the emerging research tradition on children of immigrants in Europe (Crul and Schneider 2010; Crul et al. 2012), the analysis shows that only $13 \%$ of QMR-E articles accounts for migrants' generation. While the classification of generation was the second most highly studied category between 2011 and 2012, afterwards there has been a decreasing trend. Considering the urgency of the problems surrounding the children of migrants, there is a need for immediate academic attention on this issue.

\subsubsection{Geographical Distribution}

According to this descriptive analysis, the UK is the most frequently studied country. Together with Ireland, the UK counted for $41 \%$ of the QMR-E research sites. On the one hand, this finding is not surprising, since both data sources are based in the UK and are written in English. On the other hand, the journal selection and language biases are not the only factors that can explain the high share of the UK as the research case. We need to think of other conditions that make the British context a fertile soil for migration research in general and qualitative migration research in particular. Some of these factors include: long history of migratory movements, official acknowledgement of demographic diversity, longstanding academic institutions on migration, and their strong capacity to draw research funding. After the UK 
Table 2.3 Geographical distribution of research sites over time (figures are in numbers of articles)

\begin{tabular}{l|l|l|l|l|l}
\hline & $\begin{array}{l}\text { UK }+ \\
\text { Ireland }\end{array}$ & $\begin{array}{l}\text { Western } \\
\text { Europe }\end{array}$ & $\begin{array}{l}\text { Northern } \\
\text { Europe }\end{array}$ & $\begin{array}{l}\text { Southern } \\
\text { Europe }\end{array}$ & $\begin{array}{l}\text { C. and } \\
\text { E. Europe }\end{array}$ \\
\hline 2000 & 5 & 0 & 2 & 1 & 0 \\
\hline $2001-2002$ & 16 & 13 & 1 & 5 & 1 \\
\hline $2003-2004$ & 14 & 17 & 6 & 13 & 6 \\
\hline $2005-2006$ & 38 & 20 & 2 & 12 & 1 \\
\hline $2007-2008$ & 21 & 21 & 4 & 12 & 6 \\
\hline $2009-2010$ & 37 & 24 & 3 & 12 & 3 \\
\hline $2011-2012$ & 37 & 22 & 23 & 13 & 6 \\
\hline $2013-2014$ & 44 & 20 & 17 & 24 & 6 \\
\hline $2015-2016$ & 43 & 40 & 13 & 22 & 8 \\
\hline $\begin{array}{l}\text { Total (in \% of } \\
\text { QMR-E) }\end{array}$ & $\mathbf{2 5 5}(41 \%)$ & $\mathbf{1 7 7}(28 \%)$ & $\mathbf{7 1}(11 \%)$ & $\mathbf{1 1 4}(18 \%)$ & $\mathbf{3 7}(6 \%)$ \\
\hline
\end{tabular}

Western Europe includes Germany, France, the Netherlands, Belgium and Switzerland; Northern Europe: Norway, Sweden, Finland, and Demark; Southern Europe: Spain, Italy, Portugal, and Greece; and Central and Eastern Europe: Former Yugoslavia and former Soviet Union states in the region

(238 articles), Germany (66) and the Netherlands (54) are the most studied cases by qualitative migration researchers. France (47), despite the long history of migration, lags behind other Western European cases.

As Table 2.3 shows, the distribution of country context has become much diverse over time. While in the first half of the 2000s the UK and Western Europe heavily dominated the country case selection of QMR-E, recently qualitative migration researchers study much diverse European contexts. This is probably due to the consolidation of more recent countries of migration, e.g. Spain, Italy and Greece, the enlargement of the European Union, and the incorporation of Eastern and Central European countries. The number of studies including South European cases is increasing steadily. Italy being the most studied country in this European geographical area, followed by Spain (Table 2.4). Although we have found only few QMR-E articles focusing on one or more country cases from Central and Eastern Europe, this number has been increasing recently. One of the surprising findings from our research was the position of Northern Europe. As Table 2.3 demonstrates, in the aftermath of 2011, North Europe has emerged as one of the major sites of QMRE. Three out of four QMR articles that consist of a North European case were published during the last 6 years.

When we look at the distribution of countries of origin, ${ }^{5}$ Central and Eastern Europe is by far the most studied sending region. This is followed by South Asia, which consists of former colonies of the British Empire. According to our analysis, Turkey by itself was the third most highly studied sending country. While migrants from Middle East and North Africa did not have much presence in QMR-E between

\footnotetext{
${ }^{5}$ Note that only those QMR-E articles studying one or more migrant groups had a code for country of origin. Not all QMR-E articles included a migrant group into their study.
} 
Table 2.4 Country distribution of research sites between 2000 and 2016 (figures are in number of articles)

\begin{tabular}{l|l|l|r|l|l}
\hline Western Europe & 177 & South Europe & 114 & Northern Europe & 71 \\
\hline Germany & 66 & Italy & 55 & Denmark & 23 \\
\hline Netherlands & 54 & Spain & 39 & Sweden & 21 \\
\hline France & 47 & Greece & 15 & Norway & 21 \\
\hline Belgium & 17 & Portugal & 13 & Finland & 8 \\
\hline
\end{tabular}

Table 2.5 Geographical distribution of countries of origin

\begin{tabular}{l|l|l}
\hline & Number of articles & \% in QMR-E \\
\hline Central and Eastern Europe & 68 & 10.8 \\
\hline South Asia & 37 & 5.9 \\
\hline MENA & 28 & 4.5 \\
\hline Caribbean & 14 & 2.2 \\
\hline Turkey & 34 & 5.4 \\
\hline China & 10 & 1.6 \\
\hline
\end{tabular}

Central and Eastern Europe: former Yugoslavia and former Soviet Union states in the region; South Asia: Pakistan, India, Bangladesh; MENA: countries in Arabian Peninsula, Syria, Iraq, Iran, and North Africa (Tunisia, Morocco, Algeria, Libya, and Egypt)

2000 and 2016, we expect that this situation will change in the coming years. It is important to note that Morocco is a major sending country and it has been the highest studied sending country in the MENA region. Almost half of the QMR-E articles studying migrants from MENA focused on Moroccans (Table 2.5).

\subsubsection{Multi-level of Analysis}

In this part, we examined the different levels of analysis that each QMR-E article focused on. We have distinguished four different levels: national (level of nationstate), local (level of sub-national regions, cities, towns, municipalities and neighbourhoods), European, and transnational. These levels, for us, signify the level of generalization that each study targets. In this respect, it is different from study's location or unit of analysis. ${ }^{6}$

According to our research, national-level analysis has dominated the QMRE. More than half of the studies consider their research within the scope of nationstates. However, as Table 2.6 shows, there has been a rise in the number of studies

\footnotetext{
${ }^{6}$ For instance, Kreuzberg can be the single research site of a study, then we classify the level of analysis depending on the scale in which the findings are discussed: only referring to Kreuzberg (local-level), or generalized for Berlin (city-level) or for Germany (national-level). If the study aims to bring an explanation at the level of Europe, then it is coded as European-level. Lastly, if the study explicitly adopts a transnational perspective, then it is coded as transnational level. It must be noted that the same article can be coded with multiple levels of analysis.
} 
Table 2.6 Distribution of different levels of analysis over time (figures are numbers of articles)

\begin{tabular}{l|l|l|l|l}
\hline & National & Local & European & Transnational \\
\hline 2000 & 5 & 1 & 0 & 0 \\
\hline $2001-2002$ & 19 & 8 & 8 & 9 \\
\hline $2003-2004$ & 28 & 12 & 5 & 16 \\
\hline $2005-2006$ & 43 & 10 & 6 & 17 \\
\hline $2007-2008$ & 42 & 7 & 2 & 25 \\
\hline $2009-2010$ & 41 & 13 & 7 & 14 \\
\hline $2011-2012$ & 60 & 11 & 10 & 31 \\
\hline $2013-2014$ & 59 & 24 & 4 & 29 \\
\hline $2015-2016$ & 61 & 25 & 9 & 16 \\
\hline Total & $\mathbf{3 5 8}(\mathbf{5 7 \%})$ & $\mathbf{1 1 1}(\mathbf{1 8 \% )}$ & $\mathbf{5 1} \mathbf{( 8 \% )}$ & $\mathbf{1 5 7}(\mathbf{2 5 \% )}$ \\
\hline
\end{tabular}

at local levels. This follows the emerging trend of going from a state-centric to a local-centred analysis, where cities are becoming units of analysis of diversity policies. This has been, for instance, at the centre of a special issue on 'the local turn' in migration studies, which argued for the need to promote multi-level analysis from within a city point of view (Zapata-Barrero et al. 2017).

The analysis also shows that the calls for transnationalism as a distinctive research framework of analysis in migration studies in the early 1990s (Schiller et al. 1992; Basch et al. 1994) demonstrate a strong presence in the post-2000 era. One fourth of the QMR-E articles referred to transnational level in their analysis.

\subsubsection{Topics}

In this last part of the analysis, we examined the key topics that QMR-E articles have been focusing on. The first striking finding is the dominance of the topic of identity in QMR-E in the last 16 years. This topic included the studies working on ethnicity, belonging, culture, race, religion, and language. Forty percent of QMR-E articles have focused on one or more aspects of the identity topic. After the topic of identity, policy and integration have been highly studied topics by qualitative migration researchers in Europe. As Fig. 2.7 demonstrates, there has been a growing scholarly interest on the topics of policy, integration, and mobility.

We have also had some surprising results such as declining number of QMR-E articles on youth and forced migration. While the topic of migrant youth was rising rapidly between 2009 and 2011, today, we observe a declining pattern. Considering the pressing problems of youth with migrant origins, this topic needs urgent retaking by qualitative migration researchers. The other topic that demonstrated a declining pattern was forced migration. In the view of recent refugee flows into Europe, this was an unexpected result. Yet, we must note that there are ample specialized academic journals on forced migration. Therefore, rather than a declining academic interest on the topic, as we noted earlier, scholars working on forced migration 


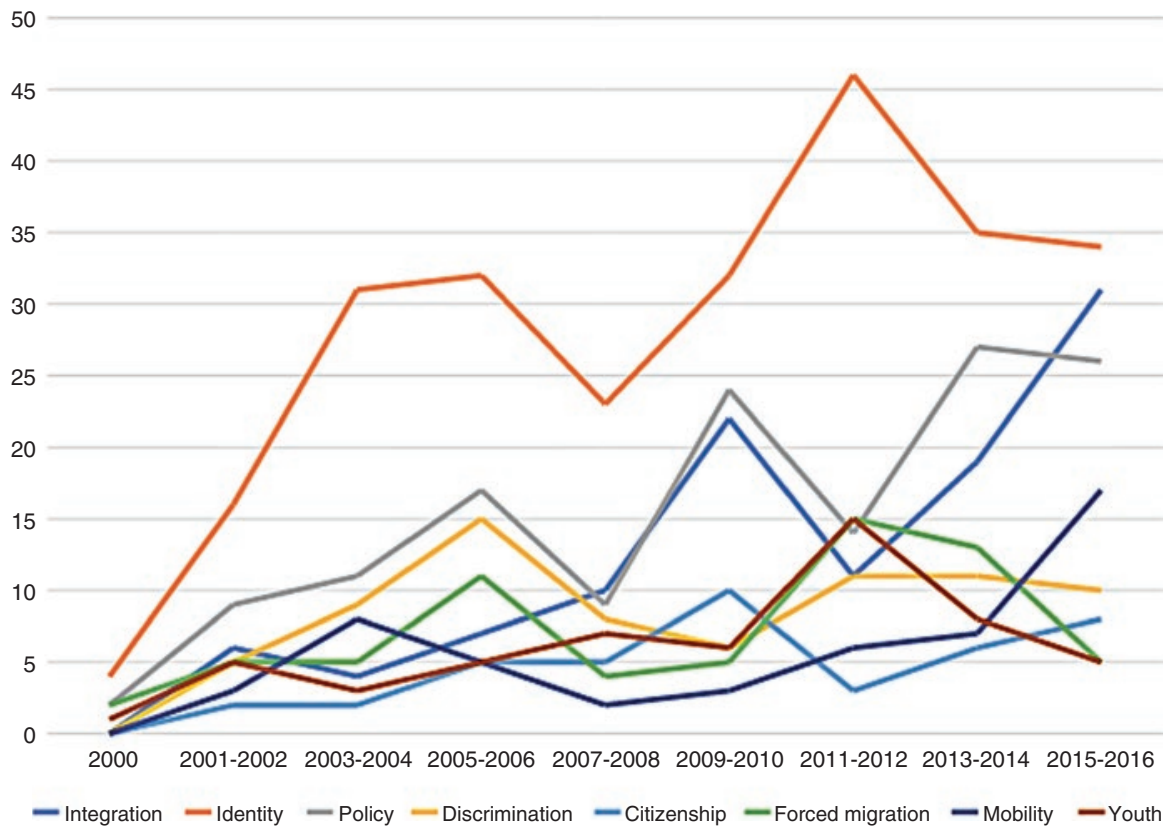

Fig. 2.7 Number of topics studied by QMR-E articles between 2000 and 2016 (Note: Each topic included a set of codes that served to identify research area/topic of each article: identity: identity, ethnicity, belonging, culture, race, religion, and language; integration: integration, incorporation, inclusion, and assimilation; discrimination: discrimination, exclusion, inequality, and islamophobia; policy: policy and policy-analysis; citizenship: citizenship and naturalization; forced migration: asylum, refugee, and forced migration; mobility: mobility and border; youth: youth, young, and second generation)

Table 2.7 Number of topics studied by QMR-E articles between 2000 and 2016

\begin{tabular}{l|l|l}
\hline & Number & \% to Total QMR-E \\
\hline Integration & 110 & 17.5 \\
\hline Identity & 253 & 40.4 \\
\hline Policy & 139 & 22.2 \\
\hline Discrimination & 75 & 12.0 \\
\hline Citizenship & 41 & 6.5 \\
\hline Forced migration & 65 & 10.4 \\
\hline Mobility & 51 & 8.1 \\
\hline Youth & 55 & 8.8 \\
\hline
\end{tabular}

might prefer journals such as the Forced Migration Review, the Journal of Refugee Studies, etc. as their primary publication outlet.

While the topic of discrimination ranked as the third most studied issue between 2003 and 2007, in the recent years it left its place to the studies of integration and mobility. The studies on citizenship have been more or less stable during this period (Table 2.7). 


\subsection{From Description to Generalization: Identifying Patterns, Gaps, and New Directions}

The purpose of this exploratory chapter has been to identify patterns and analyse continuities and changes in QMR-E. This research has been highly descriptive, yet from this level of analysis we can reach some tentative generalizations.

The first, and probably most important one, is that QMR-E is not one unified body of studies, but highly diverse in terms of its qualitative research methods, designs, research sites and groups, multi-levels of analysis, and topics. Overtime patterns show that qualitative migration research is not separate from the context it studies. On the contrary, it reflects unfolding migration dynamics, social and political agendas, rising conflicts and controversies with respect to migration issues. Therefore, empirical reality in Europe and in the world continuously defines and shapes the landscape of QMR-E.

As this exploratory descriptive analysis has shown, migration studies in general and qualitative migration research in particular are rapidly growing in numbers. Despite this significant quantity, there are some research tools and areas that have received less academic attention than others. While QMR-E has become much diverse over the last 16 years in terms of the research tools and data collection methods used by the researchers, the field can still benefit from incorporation of certain under-used qualitative tools. For instance, historical analysis has been largely ignored by qualitative migration researchers in Europe. New research tools, such as visual methods and internet-mediated research still have a marginal place in the field. Despite its increasing numbers, comparative research in European migration studies can gain more presence. We believe that qualitative migration research can highly benefit from the inclusion of new qualitative techniques and comparative designs.

Despite the recent calls for going beyond methodological nationalism, we observed that nation-state based analyses still preserve their dominance in the field. Drawing on the relevant literature, we propose two ways of encountering methodological nationalism: first, accounting for multiple and intersecting identities of migrants rather than reducing them only to their ethnic/national origins. Second, considering the migration phenomenon at the intersection of multiple levels including local, national, and transnational.

This exploratory analysis also demonstrated that some of the research areas have been less studied than others. While the issues of integration, identity, and mobility have framed the current state of art, the issues of gender and youth have been largely overlooked in qualitative migration research. While feminization of migratory flows has been demonstrated a long time ago, there is still no sufficient attention on how migration processes affect men and women differently. Moreover, beyond including women migrants as objects of analysis, scholars need to pay more attention to gendered power relations and how gender intersects with race, ethnicity, and class. In the same way, young people with a migrant background have been another understudied area. While in the US there is a well-established research tradition on 
children of immigrants (for example, see Portes and Zhou 1993; Portes and Rumbaut 2001; Kasinitz et al. 2009), in Europe, qualitative research on second generation demands more attention.

\section{Annex: Selected Research Topics Provided by IMISCOE on Researcher's Profile Page}

- Assimilation

- Asylum

- Border

- Citizenship

- Culture

- Discrimination

- Diversity

- Education

- Entrepreneurship

- Ethical issues

- Ethnicity

- European Union

- Exclusion

- Forced migration

- Gender

- Globalization

- High-skilled

- Human Rights

- Identity

- Immigration

- Incorporation

- Inequality

- Institutions

- Integration

- Interculturalism

- Islamophobia

- Labor

- Media

- Minority Rights

- Mobility

- Multiculturalism

- Nationalism

- Naturalization

- Organisations

- Policy 
- Public Opinion

- Race

- Radicalization

- Refugees

- Religion

- Return migration

- Second-generation

- Security

- Segregation

- Social Capital

- Transnationalism

\section{References}

Amelina, A., \& Faist, T. (2012). De-naturalizing the national in research methodologies: Key concepts of transnational studies in migration. Ethnic and Racial Studies, 35(10), 1707-1724. https://doi.org/10.1080/01419870.2012.659273.

Anderson, B. (2010). Mobilizing migrants, making citizens: Migrant domestic workers as political agents. Ethnic and Racial Studies, 33(1), 60-74. https://doi.org/10.1080/ 01419870903023660.

Basch, L. G., Schiller, N. G., \& Blanc, C. S. (1994). Nations unbound: Transnational projects, postcolonial predicaments, and deterritorialized Nation-States. New York: Gordon and Breach Publishers.

Batnitzky, A., \& McDowell, L. (2013). The emergence of an 'ethnic economy'? The spatial relationships of migrant workers in London's health and hospitality sectors. Ethnic and Racial Studies, 36(12), 1997-2015. https://doi.org/10.1080/01419870.2012.681673.

Bauder, H. (2008). Media discourse and the new German immigration law. Journal of Ethnic and Migration Studies, 34(1), 95-112. https://doi.org/10.1080/13691830701708783.

Bloemraad, I. (2013). The promise and pitfalls of comparative research design in the study of migration. Migration Studies, 1(1), 27-46. https://doi.org/10.1093/migration/mns035.

Bouras, N. (2013). Shifting perspectives on transnationalism: Analysing Dutch political discourse on Moroccan migrants' transnational ties, 1960-2010. Ethnic and Racial Studies, 36(7), 12191231. https://doi.org/10.1080/01419870.2013.785580.

Cappiali, T. M. (2016). Activism of immigrants in vulnerable conditions and radical-left allies: A case study of Italy's struggle of the crane. Journal of Ethnic and Migration Studies, 42(15), 2508-2527. https://doi.org/10.1080/1369183X.2016.1169917.

Castles, S., \& Kosack, G. (1973). Immigrant workers and class structure in Western Europe. London: Oxford University Press.

Castles, S., \& Miller, M. J. (1993). The age of migration. New York: Guilford Press.

Cerna, L. (2016). The crisis as an opportunity for change? High-skilled immigration policies across Europe. Journal of Ethnic and Migration Studies, 42(10), 1610-1630. https://doi.org/1 $0.1080 / 1369183$ X.2016.1162355.

Crul, M., \& Schneider, J. (2010). Comparative integration context theory: Participation and belonging in new diverse European cities. Ethnic and Racial Studies, 33(7), 1249-1268. https://doi. org/10.1080/01419871003624068.

Crul, M., Schneider, J., \& Lelie, F. (Eds.). (2012). The European second generation compared: Does the integration context matter? Amsterdam: Amsterdam University Press. 
de Graauw, E., \& Vermeulen, F. (2016). Cities and the politics of immigrant integration: A comparison of Berlin, Amsterdam, New York City, and San Francisco. Journal of Ethnic and Migration Studies, 42(6), 989-1012. https://doi.org/10.1080/1369183X.2015.1126089.

De Tona, C., \& Lentin, R. (2011). 'Building a platform for our voices to be heard': Migrant women's networks as locations of transformation in the Republic of Ireland. Journal of Ethnic and Migration Studies, 37(3), 485-502. https://doi.org/10.1080/1369183X.2011.526780.

Dedieu, J.-P., \& Mbodj-Pouye, A. (2016). The first collective protest of black African migrants in postcolonial France (1960-1975): A struggle for housing and rights. Ethnic and Racial Studies, 39(6), 958-975. https://doi.org/10.1080/01419870.2015.1081964.

Ekman, M. (2015). Online Islamophobia and the politics of fear: Manufacturing the green scare. Ethnic and Racial Studies, 38(11), 1986-2002. https://doi.org/10.1080/01419870.2 015.1021264 .

Fedyuk, O. (2012). Images of transnational motherhood: The role of photographs in measuring time and maintaining connections between Ukraine and Italy. Journal of Ethnic and Migration Studies, 38(2), 279-300. https://doi.org/10.1080/1369183X.2012.646422.

Gawlewicz, A. (2015). "We inspire each other, subconsciously": The circulation of attitudes towards difference between Polish migrants in the UK and their significant others in the sending society. Journal of Ethnic and Migration Studies, 41(13), 2215-2234. https://doi.org/10.1 080/1369183X.2015.1045463.

Gebhardt, D. (2016). When the state takes over: Civic integration programmes and the role of cities in immigrant integration. Journal of Ethnic and Migration Studies, 42(5), 742-758. https://doi. org/10.1080/1369183X.2015.1111132.

Glick Schiller, N. (2008). Beyond methodological ethnicity: Local and transnational pathways of immigrant incorporation. Willy Brandt Series of Working Papers in International Migration and Ethnic Relations, 2(08).

Glick Schiller, N., \& Çağlar, A. (2013). Locating migrant pathways of economic emplacement: Thinking beyond the ethnic lens. Ethnicities, 13(4), 494-514. https://doi. org/10.1177/1468796813483733.

Helbling, M. (2010). Switzerland: Contentious citizenship attribution in a federal state. Journal of Ethnic and Migration Studies, 36(5), 793-809. https://doi.org/10.1080/13691831003764334.

Hickman, M. J. (2011). Census ethnic categories and second-generation identities: A study of the Irish in England and Wales. Journal of Ethnic and Migration Studies, 37(1), 79-97. https://doi. org/10.1080/1369183X.2011.523005.

Howard, M. M. (2010). The impact of the far right on citizenship policy in Europe: Explaining continuity and change. Journal of Ethnic and Migration Studies, 36(5), 735-751. https://doi. org/10.1080/13691831003763922.

Kasinitz, P., Mollenkopf, J. H., Waters, M. C., \& Holdaway, J. (2009). Inheriting the city: The children of immigrants come of age. New York: Russell Sage Foundation.

King, R. (2009). Editorial: Ten issues per year. Journal of Ethnic and Migration Studies, 35(1), 1-1. https://doi.org/10.1080/13691830802488756.

King, R., Money, J., \& Murawska, M. (2011). Twenty years of JEMS: A geographical content analysis. Journal of Ethnic and Migration Studies, 37(9), 1539-1550. https://doi.org/10.1080/ 1369183X.2011.623632.

Kloosterman, R. C., Rusinovic, K., \& Yeboah, D. (2016). Super-diverse migrants-Similar trajectories? Ghanaian entrepreneurship in the Netherlands seen from a mixed embeddedness perspective. Journal of Ethnic and Migration Studies, 42(6), 913-932. https://doi.org/10.1080 /1369183X.2015.1126091.

Konzett-Smoliner, S. (2016). Return migration as a 'family project': Exploring the relationship between family life and the readjustment experiences of highly skilled Austrians. Journal of Ethnic and Migration Studies, 42(7), 1094-1114. https://doi.org/10.1080/13691 83X.2016.1138853.

Lee, J., Carling, J., \& Orrenius, P. (2014). The international migration review at 50: Reflecting on half a century of international migration research and looking ahead. International Migration Review, 48, S3-S36. https://doi.org/10.1111/imre.12144. 
Levitt, P., \& Jaworsky, B. N. (2007). Transnational migration studies: Past developments and future trends. Annual Review of Sociology, 33(1), 129-156. https://doi.org/10.1146/annurev. soc.33.040406.131816.

Levitt, P., \& Schiller, N. G. (2004). Conceptualizing simultaneity: A transnational social field perspective on society. International Migration Review, 38(3), 1002-1039. https://doi. org/10.1111/j.1747-7379.2004.tb00227.x.

Liversage, D. A. (2009). Finding a path: Investigating the labour market trajectories of high-skilled immigrants in Denmark. Journal of Ethnic and Migration Studies, 35(2), 203-226. https://doi. org/10.1080/13691830802586195.

Loch, D. D. (2009). Immigrant youth and urban riots: A comparison of France and Germany. Journal of Ethnic and Migration Studies, 35(5), 791-814. https://doi.org/10.1080/13691830902826236.

Long, J., Hylton, K., \& Spracklen, K. (2014). Whiteness, blackness and settlement: Leisure and the integration of new migrants. Journal of Ethnic and Migration Studies, 40(11), 1779-1797. https://doi.org/10.1080/1369183X.2014.893189.

Lutz, H. (2010). Gender in the migratory process. Journal of Ethnic and Migration Studies, 36(10), 1647-1663. https://doi.org/10.1080/1369183X.2010.489373.

Maly, I. (2016). Detecting social changes in times of superdiversity: An ethnographic linguistic landscape analysis of Ostend in Belgium. Journal of Ethnic and Migration Studies, 42(5), 703-723. https://doi.org/10.1080/1369183X.2015.1131149.

Martiniello, M. (2017). Visual sociology approaches in migration, ethnic and racial studies. Ethnic and Racial Studies, O(0), 1-7. https://doi.org/10.1080/01419870.2017.1295163.

Martiniello, M., \& Rath, J. (Eds.). (2010). Selected studies in international migration and immigrant incorporation. Amsterdam: Amsterdam University Press.

Martiniello, M., \& Rath, J. (Eds.). (2012). An introduction to international migration studies: European perspective. Amsterdam: Amsterdam University Press.

Martiniello, M., \& Rath, J. (2014). Immigrant incorporation studies in Europe: An introduction. In M. Martiniello \& J. Rath (Eds.), An introduction to immigrant incorporation studies: European perspectives (pp. 11-21). Amsterdam: Amsterdam University Press.

Matejskova, T., \& Antonsich, M. (Eds.). (2015). Governing through diversity: Migration societies in post-multiculturalist times. Basingstoke: Palgrave Macmillan.

McDowell, L. (2009). Old and new European economic migrants: Whiteness and managed migration policies. Journal of Ethnic and Migration Studies, 35(1), 19-36. https://doi. org/10.1080/13691830802488988.

McGarrigle, J. (2016). Islam in urban spaces: The residential incorporation and choices of Muslims in Lisbon. Journal of Ethnic and Migration Studies, 42(3), 437-457. https://doi.org/10.1080/1 369183X.2015.1065715.

Menz, G. (2002). Patterns in EU labour immigration policy: National initiatives and European responses. Journal of Ethnic and Migration Studies, 28(4), 723-742. https://doi.org/10.1080/ 1369183021000032281.

Parella, S., Petroff, A., \& Solé, C. (2013). The upward occupational mobility of immigrant women in Spain. Journal of Ethnic and Migration Studies, 39(9), 1365-1382. https://doi.org/10.1080 /1369183X.2013.815395.

Plöger, J., \& Becker, A. (2015). Social networks and local incorporation—Grounding high-skilled migrants in two German cities. Journal of Ethnic and Migration Studies, 41(10), 1517-1535. https://doi.org/10.1080/1369183X.2015.1015407.

Portes, A., \& Rumbaut, R. G. (2001). Legacies: The story of the immigrant second generation. Berkeley: University of California Press.

Portes, A., \& Zhou, M. (1993). The new Second generation: Segmented assimilation and its Variants. The Annals of the American Academy of Political and Social Science, 530(1), 74-96. https://doi.org/10.1177/0002716293530001006.

Qureshi, K. (2016). Shehri (city) brides between Indian Punjab and the UK: Transnational hypergamy, Sikh women's agency and gendered geographies of power. Journal of Ethnic and Migration Studies, 42(7), 1216-1228. https://doi.org/10.1080/1369183X.2015.1068107. 
Riccio, D. B. (2008). West African transnationalisms compared: Ghanaians and Senegalese in Italy. Journal of Ethnic and Migration Studies, 34(2), 217-234. https://doi. org/10.1080/13691830701823913.

Runfors, A. (2016). What an ethnic lens can conceal: The emergence of a shared racialised identity position among young descendants of migrants in Sweden. Journal of Ethnic and Migration Studies, 42(11), 1846-1863. https://doi.org/10.1080/1369183X.2016.1153414.

Ryan, L. (2003). Moving spaces and changing places: Irish women's memories of emigration to Britain in the 1930s. Journal of Ethnic and Migration Studies, 29(1), 67-82. https://doi.org/10 $.1080 / 1369183032000076722$.

Ryan, L. (2015). Friendship-making: Exploring network formations through the narratives of Irish highly qualified migrants in Britain. Journal of Ethnic and Migration Studies, 41(10), 1664 1683. https://doi.org/10.1080/1369183X.2015.1015409.

Schiller, P. N. G., \& Çağlar, P. A. (2009). Towards a comparative theory of locality in migration studies: Migrant incorporation and city scale. Journal of Ethnic and Migration Studies, 35(2), 177-202. https://doi.org/10.1080/13691830802586179.

Schiller, N. G., Basch, L. G., \& Blanc, C. S. (1992). Towards a transnational perspective on migration: Race, class, ethnicity, and nationalism reconsidered. New York: New York Academy of Sciences.

Schrooten, M., Salazar, N. B., \& Dias, G. (2016). Living in mobility: Trajectories of Brazilians in Belgium and the UK. Journal of Ethnic and Migration Studies, 42(7), 1199-1215. https://doi. org/10.1080/1369183X.2015.1089160.

Simpson, S.-A. (2015). Negotiating places of incorporation: Comparing the practices of community development organisations in immigration and incorporation. Journal of Ethnic and Migration Studies, 41(12), 1978-2000. https://doi.org/10.1080/1369183X.2015.1022515.

Søholt, S., \& Lynnebakke, B. (2015). Do immigrants' preferences for neighbourhood qualities contribute to segregation? The case of Oslo. Journal of Ethnic and Migration Studies, 41(14), 2314-2335. https://doi.org/10.1080/1369183X.2015.1054795.

Statham, P. (2016). Note from the editor. Journal of Ethnic and Migration Studies, 42(1), 1-2. https://doi.org/10.1080/1369183X.2015.1118870.

van Meeteren, M., Mascini, P., \& van den Berg, D. (2015). Trajectories of economic integration of amnestied immigrants in Rotterdam. Journal of Ethnic and Migration Studies, 41(3), 448-469. https://doi.org/10.1080/1369183X.2014.924846.

Vertovec, S. (1999). Conceiving and researching transnationalism. Ethnic and Racial Studies, 22(2), 447-462. https://doi.org/10.1080/014198799329558.

Vertovec, S. (2007). Super-diversity and its implications. Ethnic and Racial Studies, 30(6), 1024 1054. https://doi.org/10.1080/01419870701599465.

Vertovec, S. (2010). Towards post-multiculturalism? Changing communities, conditions and contexts of diversity. International Social Science Journal, 61(199), 83-95. https://doi. org/10.1111/j.1468-2451.2010.01749.x.

Vertovec, S. (Ed.). (2015). Routledge international handbook of diversity studies. London/New York: Routledge.

Verwiebe, R., Seewann, L., Wolf, M., \& Hacioglu, M. (2016). "I have to be very good in what I do". Marginalisation and discrimination in the career-entry phase - experiences and coping strategies among university graduates with a migrant background in Austria. Journal of Ethnic and Migration Studies, 42(15), 2468-2490. https://doi.org/10.1080/13691 83X.2016.1169160.

Walaardt, T. (2013). From heroes to vulnerable victims: labelling Christian Turks as genuine refugees in the 1970s. Ethnic and Racial Studies, 36(7), 1199-1218. https://doi.org/10.1080/0141 9870.2013.783706.

Wiesböck, L., Verwiebe, R., Reinprecht, C., \& Haindorfer, R. (2016). The economic crisis as a driver of cross-border labour mobility? A multi-method perspective on the case of the Central European Region. Journal of Ethnic and Migration Studies, 42(10), 1711-1727. https://doi.org /10.1080/1369183X.2016.1162354. 
Wimmer, A., \& Schiller, N. G. (2003). Methodological nationalism, the social sciences, and the study of migration: An essay in historical epistemology. International Migration Review, 37(3), 576-610. https://doi.org/10.1111/j.1747-7379.2003.tb00151.x.

Zapata-Barrero, R., Caponio, T., \& Scholten, P. (2017). Theorizing the 'local turn' in a multi-level governance framework of analysis: A case study in immigrant policies. International Review of Administrative Sciences, 83(2), 241-246. https://doi.org/10.1177/0020852316688426.

Open Access This chapter is licensed under the terms of the Creative Commons Attribution 4.0 International License (http://creativecommons.org/licenses/by/4.0/), which permits use, sharing, adaptation, distribution and reproduction in any medium or format, as long as you give appropriate credit to the original author(s) and the source, provide a link to the Creative Commons license and indicate if changes were made.

The images or other third party material in this chapter are included in the chapter's Creative Commons license, unless indicated otherwise in a credit line to the material. If material is not included in the chapter's Creative Commons license and your intended use is not permitted by statutory regulation or exceeds the permitted use, you will need to obtain permission directly from the copyright holder.

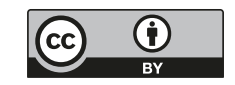

